PINHEIRO.M.M.V.P.S. ${ }^{(*)}$, MELO,L.F. ${ }^{(*)}$, BOTT,T.R. ${ }^{(* *)}$ and PINHEIRO,J.D. ${ }^{(*)}$

(*) University of Minho, C.Q.P.A./I.N.I.C., 4700 Braga, Portugal

(**) University of Birmingham, Chem.Eng.Departm., U.K.

\title{
INTRODUCTION
}

Biofouling, like other types of fouling, may cause serious problems in heat transfer equipment. In general, the formation of deposits is dependent on several physical and chemical variables, but in what respects bioufouling other conditions have to be considered. These are related with the growth and reproduction of microorganisms in the fluid and also in the films. In this work reference is made specially to the effects on bioufouling of:

- fluid velocity;

- surface characteristics;

- surface and fluid temperature;

- $\mathrm{pH}$ of the fluid;

- nutrient concentration;

- presence of inorganic suspended particles

\section{EFFECT OF FLUID VELOCITY}

Taking into account the sequence of processes that contribute to the formation of biofilms(1), it is obvious that the fluid velocity is of fundamental influence to the phenomena, though its effects may be contradictory. It can be said that lower velocities tend to favour initial colonization of surfaces due to the characteristics of the laminar layer that facilitates the anchorage of microorganisms. But, on the other hand, this low velocity layer constitutes an obstacle to the diffusion of nutrients and oxygen indispensable to the metabolism of the attached cells. In this way, higher velocities are considered more favourable to the renewal of nutrients near the surfaces, allowing a faster growth of the microorganisms. Nevertheless, high values of shear stress associated with higher velocities induce the removal of deposits. So, in general, higher velocities tend to produce thinner films than lower velocities. However, it was shown (2) that the influence of higher velocities is not restricted to the erosive effect. In fact, when the fluid velocity. was increased from $0.03 \mathrm{~m} / \mathrm{s}$ to $0.3 \mathrm{~m} / \mathrm{s}$, the uptake of oxygen in the biofilm was $60 \%$ higher. These results lead to the conclusion that the microbial activity in the film was increased, although it has lower thickness.

Summarizing, one may conclude that the true effect of increasing the fluid velocity is the compaction of the film, otherwise Sanders (2) would have found lower values for the oxygen uptake.

The compaction of biofilm under conditions of higher fluid velocities was also studied by Bott (3). He obtained higher topographical variations in the film surface under laminar regime than with turbulent flow.

Recent experimental results obtained with a culture of Pseudomonas fluorescens (12), revealed higher film densities for higher velocities, as shown in Table 1.

The structure of the deposit (also dependent on the fluid velocity)has a relevant effect on the growth and reproduction of the attached microorga- 
TABLE 1. Film densities for different fluid velocities $\left(\mathrm{Kg} / \mathrm{m}^{3}\right)$

\begin{tabular}{lcc}
\hline $\begin{array}{c}\text { deposition } \\
\text { surface }\end{array}$ & $\overline{\mathrm{v}}=0.43 \mathrm{~m} / \mathrm{s}$ & $\overline{\mathrm{v}}=0.13 \mathrm{~m} / \mathrm{s}$ \\
\hline cooper & 43.5 & 17.3 \\
aluminium & 38.6 & 13.0 \\
brass & 25.8 & 15.2 \\
\hline
\end{tabular}

nisms. Experimental results obtained with suspended inorganic particles (4) suggest that the structure of the deposits is not uniform along the thickness of the films resulting in a more compact layer near the deposition surface and a somewhat looser one near the solid-liquid interface. The relative dimension of these layers is also an important factor in what concerns biofouling, since microbial growth is favoured by the presence of high concentrations of nutrients. Thus, a more compact structure may be a limiting factor for diffusion of those nutrients throughout the deposit. In fact, for moderate velocities, cell growth may be increased in presence of higher fluid velocities, but for much higher velocities the "active" layer become limited to the superficial layer of the deposit.

Experimental work on biofouling produced by Pseudomonas fluorescens(5) has shown that there is a relationship between microbial growth and fluid velocity. For this purpose, a biofouling model was developed (5) including terms associated with the rate of transport (cells and nutrients), adhesion and reproduction of microorganisms. The results presented in Fig. 1 were obtained by fitting this model to the experimental data.

\section{EFFECT OF SURFACE CHARACTERISTICS}

The surface characteristics are usualy related with the formation of the first layers of biofilm.

In fact, the formation of the organic conditioning film that triggers the adhesion of the first layers depends naturally on the surface characteristics, namely on its critical surface tension.

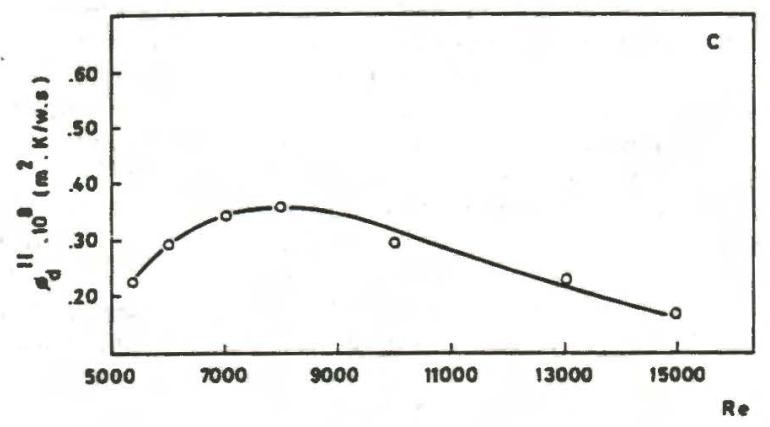

FIG. 1. Deposition flux due to microbial growth $\left(\emptyset_{\mathrm{g}}\right)$ as a function of Reynolds Number 
This property has been related to the number of the attached cells in the first layer per unit area $(6,7)$ as it can be seen in Figure 2 .

It appears that there is an interval (generaly referred in the range of 20-30 dyne $/ \mathrm{cm}$ ) for which the adhesion of microorganisms is less favourable. For these conditions, it was proved (7) that the adsorbed biofilm rectract and rolls back from the surface, indicating low adhesion capacity.

However, most enginnering materials and coatings show high capacity for adsorbing the first layers of the biofilm, presenting values of critical surface tension above the mentioned interval.

As regards the roughness of the deposition surface, it is accepted that higher surface roughness favours the anchorage of microorganisms due to the increase in the contact area. However, this effect is limited to the first layers of deposit (8) and therefore to the induction period of the overal1 process. The final thickness of the deposits is not significantly affected by this surface characteristics, but by the characteristics of the previous fouling layers that cover the surface. Nevertheless, the period of time necessary to attain the maximum thickness is enlarged, which is favourable to industrial operations.

Another surface characteristic that is often mentioned, related to the formation of biological deposits, is the toxicity of some metallic ions (9). However, the results published in the literature are not conclusive, since they appear to depend on the dominant microbial species and on the environmental condition.

Aluminium surfaces are sometimes referred (20) as the less fouled substractum, due to the toxic effect of Al $3+$ ion acting on the polyssacharide adhesive structure. Yet, Duddridge (9) concluded that brass (compared with copper, aluminium or stainless steel; prevents microbial fouling due to the leaching of $\mathrm{Zn}^{2+}$ ions - see Figure 3 .

On the other hand, copper is usually mentioned $(10,11)$ as an effective material inhibiting cellular metabolism. However, contradictory results do not confirm this antimicrobial action $(9,12)$. Table 2 refers the-results obtained when measuring the thickness and mass of deposits formed after 48 hours exposure using copper, aluminium and brass surfaces.(12)

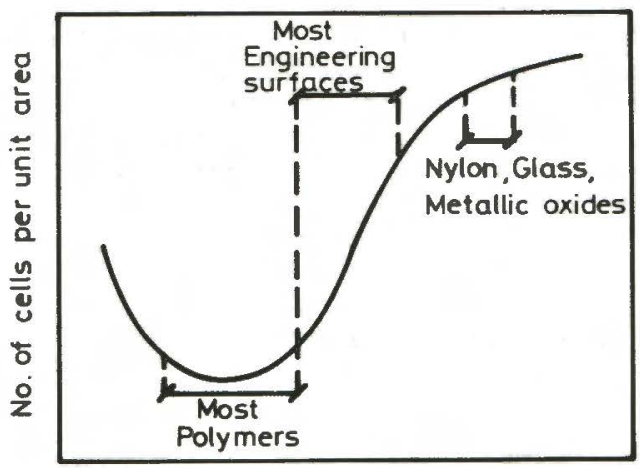

Critical surface tension

FIG. 2. Number of attached cells as a function of the critical surface tension 


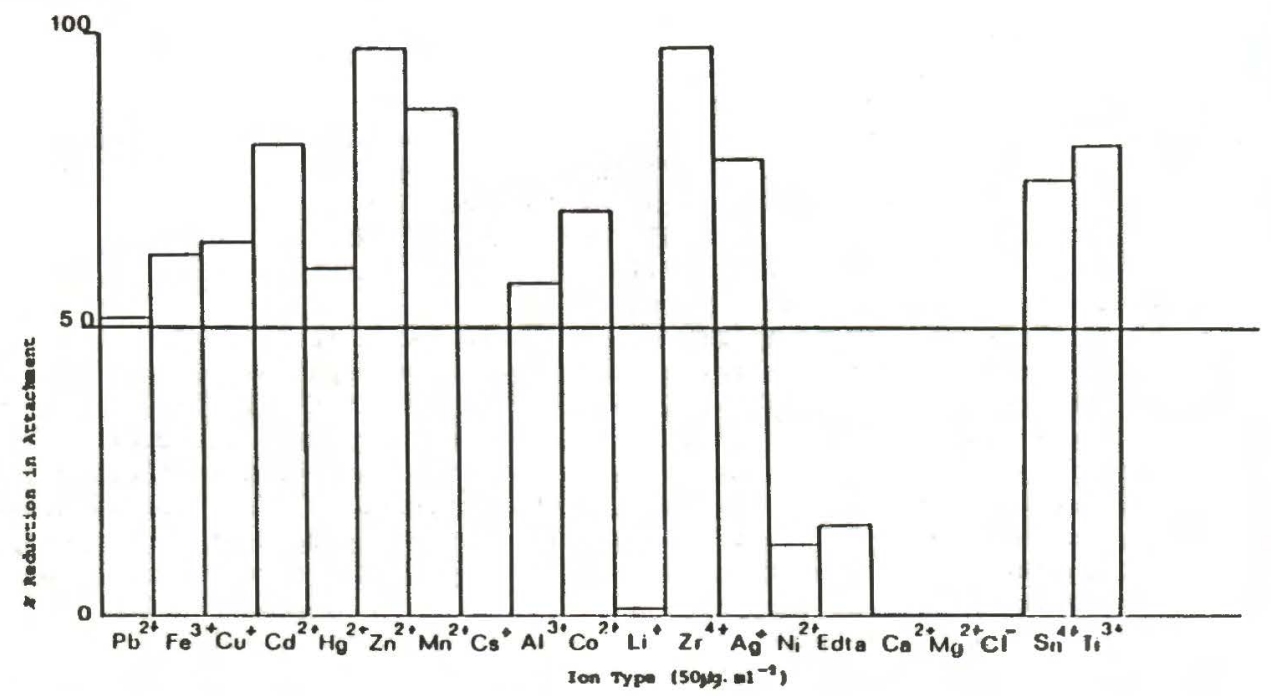

FIG. 3. Influence of metallic ions on the attachment of cells (9).

It is thought that the toxic effect of the metallic ions ceases after several layers of biofilm are formed. In these case, this effect may be responsible for retarding the overall process without eliminating it completely.

3. EFFECT OF FLUID AND SURFACE TEMPERATURE

Temperature constitutes a critical parameter in the development of biofouling. In fact, it is often found an optimum temperature range for growth of each specie of microorganism. The majority of microbial species present in contaminated waters has its optimum growth temperature between 20 and $45^{\circ} \mathrm{C}$, but there are others that can grow at lower (Psicrophilics) or higher (Thermophilics) temperatures.

Bott and Pinheiro (3) evaluated the influence of temperature in the formation of biofilms by varying it from $30^{\circ} \mathrm{C}$ to $35^{\circ} \mathrm{C}$ (Fig. 4). The increase in biofilm thickness was about $70 \%$, noting that the optimum temperature for growth of the predominant bacteria (E.coli) is $37^{\circ} \mathrm{C}$.

A similar result was obtained by Miller (13) utilizing a culture of Pseudomonas fluorescens. In fact, a variation of only $5^{\circ} \mathrm{C}$ from the optimum temperature for growth ot that microorganism resulted in a drastic decrease in the biofilm thickness.

Studies carried out in industrial cooling water systems revealed a di-

TABLE 2. Mass and thickness of deposits on different surface materials

\begin{tabular}{lll}
\hline $\begin{array}{l}\text { surface } \\
\text { material }\end{array}$ & $\begin{array}{c}\mathrm{m} \\
(\mathrm{mg})\end{array}$ & $\begin{array}{c}\mathrm{Y} \\
(\mu \mathrm{m})\end{array}$ \\
\hline copper & 4.1 & 52 \\
aluminium & 3.9 & 47 \\
brass & 2.8 & 31 \\
\hline
\end{tabular}




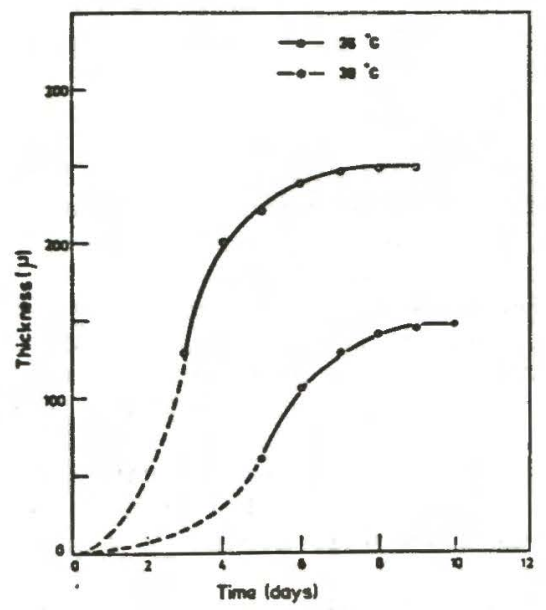

FIG. 4. Influence of temperature on biofouling

rect relation between the biofilm thickness and the ambient temperature during the year. Biological deposits increased during the summer months to which corresponds higher mean temperatures.

Results reported by Novak (15) for river water show that only minor variations in the biofilm thickness were noted when the temperatures varied from $10^{\circ} \mathrm{C}$ to $45^{\circ} \mathrm{C}$. However, in this case, other types of fouling may have been present, masking the usual effect detected in biofouling.

The majority of studies reported in the literature is concerned with the fluid temperatures, but not with the actual temperature developed at the deposition surfaces. It is thought, though, that these temperatures have a relevant effect on the process as illustrated by the results of Hattori (16) and shown in Fig. 5. Kent (10) refers that these temperatures affect the production of exopolymers by the cells and, therefore, the mechanism of adhesion to the surfaces.

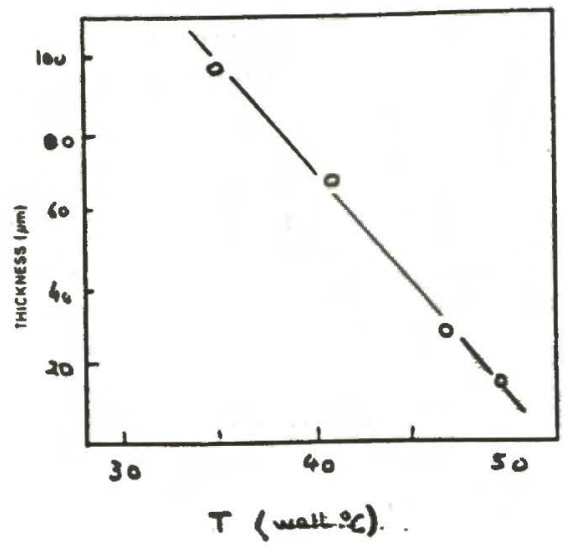

FIG. 5. Influence of the surface temperature on biofouling 
The utilization of temperatures above or below the optimum values for growth of the predominant microbial species is a potencial process for dimi. nishing the intensity of biofouling.

\section{EFFECT OF FLUID $\mathrm{pH}$}

The influence of fluid $\mathrm{pH}$ is related not only with the growth rate of the microorganisms but also with the adhesion forces at the surfaces.

As to the growth rate, the majority of microorganisms in contaminated waters has a preference for growth at a neutral $\mathrm{pH}$ (17). However, some species may growth at $\mathrm{pH}$ as 1 ow as 4.0 or as high as 9.0 (10). Experimental studies undertaken to relate the $\mathrm{pH}$ of the fluid with the microbial growth on the surfaces $(9,18)$, indicate that greater amounts of deposits are formed at $\mathrm{pH}$ coinciding with the best values for growth and reproduction of the microorganisms present in the film.

For instance, higher film densities were obtained for $\mathrm{pH}=7$ than for $\mathrm{pH}=9$, when using a culture of Pseudomonas fluorescens (12) (Table 3). Note that this microorganism shows a specific growth rate $53 \%$ higher for $\mathrm{pH}=7$ than $\mathrm{pH}=9$.

It is worth mentioning that the $\mathrm{pH}$ conditions in the solid-liquid interface may be altered by the cellular metabolism which may procude acids or alkalis.

The adhesion of macromolecules and microbial cells is also dependent on the $\mathrm{pH}$, since it can affect the distribution of electrical surface charges of materials in presence, and thus, their zeta potentials. The adhesion between these materials is increased when the corresponding zeta potencials have opposite signs.

Most usualy, the majority of bacteria have negative electrical surface charges (19), thus presenting higher facility for the adhesion to solid surfaces with positive zeta potentials.

Fletcher (20) found a higher number of adherent bacteria (Pseudomonad marina) in platinium than in glass or mica surfaces when using the pH value favourable to the growth of this microorganisms. In these circumstances, it was found that the less fouled surfaces have negative zeta potentials, while the other tested surfaces have positive zeta potentials (21).

MacRae and Evans (22) studied the adhesion of bacteria to magnetite particles in aqueous suspensions. The adhesion was higher under conditions of $\mathrm{pH}=3$ and $\mathrm{pH}=6$, for which the two substances (bacteria and magnetite) show opposite surface charges.

It can be said that the coating of solid surfaces with materials that increase the electronegativity, would reduce tha possibilities of adhesion of the great majority of bacteria.

TABLE 3. Influence of fluid $\mathrm{pH}$ on bifouling density $\left(\mathrm{Kg} / \mathrm{m}^{3}\right)$

\begin{tabular}{lll}
\hline $\begin{array}{c}\text { deposition } \\
\text { surface }\end{array}$ & $\mathrm{pH}=7$ & $\mathrm{pH}=9$ \\
\hline copper & 57.9 & 40.3 \\
aluminium & 61.0 & 41.8 \\
brass & 66.4 & 35.8 \\
\hline
\end{tabular}




\section{EFFECT OF NUTRIENT CONCENTRATION}

It is generally accepted that biofouling is directly related with the concentration of nutrients and oxygen in the fluids. As the microorganisms become attached their growth will depend on the diffusion of those elements through the film. The limit for this diffusion depends on the thickness and on the structure of the film. Kornegay and Andrews (23) report a limiting value for film thickness of $70 \mu \mathrm{m}$ through which the diffusion of oxygen is possible, but other investigators refer different values $(200 \mu \mathrm{m}, 300 \mu \mathrm{m})$ (24).

The low levels of nutrients in the deeper zones of films may result in a decrease in the production of excreted polyssacharides thus rendering films more vulnerables to shear forces. Yet, the suppression of nutrients in the fluid causes a reduction in the heat transfer resistance of the preformed films - Fig. 6. It seems that this reduction is due to the decrease in the polyssacharides production by the cells, modifying the biofilm structure and resulting in a reduction of the stagnant layer of water within that structure.

\section{PRESENCE OF INORGANIC SUSPENDED PARTICLES}

Industrials fluids contain usually, a mixture of foulants and the association of different types of fouling is often found in industrial equipment.

Experimental studies have been made to investigate the influence of kaolin particles on biofouling $(5,25)$. The induction period seems to be enlarged and it was found that a lower number of cells became attached to the surface, this fact being attributed to the tendency of microbes to cover the suspended inorganic particles (26), forming aggregates.

On the other hand, higher quantities (weights and thermal resistances) of biofilm were obtained when the asymptotic values of fouling were reached. This may be due to the new type of deposit structure or to the stimulation of atached cells growth and metabolism in the presence of kaolin. The structure is certainly different since it contains entrapped kaolin particles

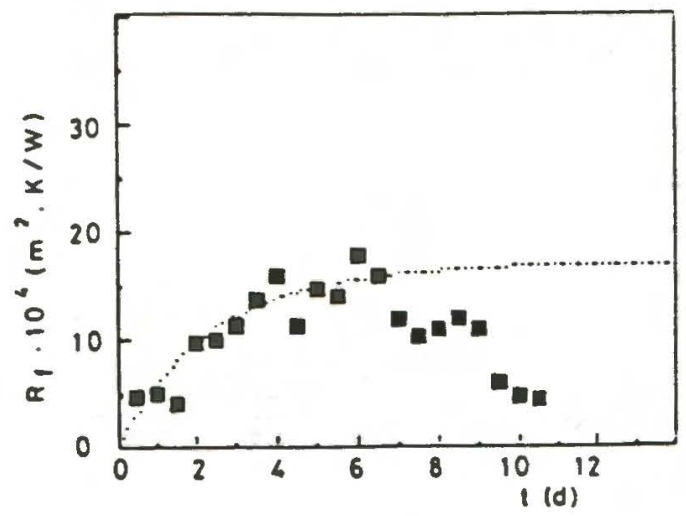

FIG. 6. Effect of the suppression of nutrients on the thermal resistance of biofilms 
which have lower values of thermal conductivity. Besides, it was found (5) that the growth and reproduction of cells in the film is increased due to the presence of these inorganic particles. This stimulation is related to the structure formed in the deposit that tends to be less compact and therefore more favourable to the diffusion of nutrients. It can also constitute a positive factor for microbial growth the possibility of inorganic particles function as a source of nutrients when entrapped in the film. In fact, kaolin particles tend to became not only colonized by microbe but also coated with organic molecules when in suspension.

7. IDENTIFICATION OF FOULING MECHANISMS THROUGH THE STUDY OF DESIGN AND OPERATING VARIABLES

It is easily recognized that research on the effects of one or more variables on biofilm formation can be of great assistance in the detection of the mechanisms controlling a fouling process.

Figure 7. presents values of the deposition flux $\varphi_{\mathrm{d}}$, as a function of the Reynolds Numbers, obtained when studying the velocity effect on fouling caused by Pseudomonas fluorescens (12). The deposition flux decreases with increasing velocities, indicating that adhesion may be governing the build-up of the deposits. In this case, however, for higher Reynolds Numbers the clear flattening of the curve shows that there is probably another mechanism affecting biofilm formation. This mechanism was though to be bacteria growth. Further studies with the same bacteria confirmed this assumption, since it was found that the amount of biofilm was highly dependent on the best conditions for growth and reproduction, namely the $\mathrm{pH}$ level (as mentioned in point 4).

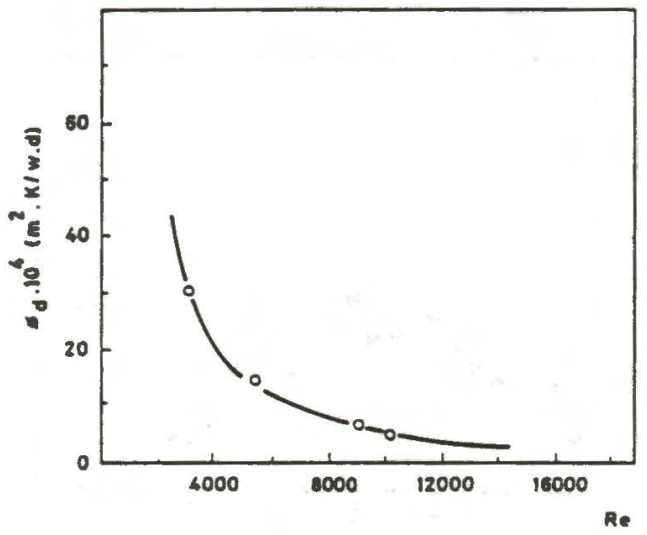

FIG. 7. Deposition flux as a function of Reynolds Numbers. 


\section{REFERENCES}

1. Maracklis, W.C. "Microbial fouling: A Process Analysis" in Int. Conf. on Fouling of Heat Transfer Equipment, Rensselaer Polythecnic Institute, Troy, II.Y., 13-17 August, 251, 1979.

2. Sanders, W.M., Ph.D. Thesis, John Hopkins University, Baltimore, U.S.A.

3. Bott, T,R, Pinheiro, M.M.V.P.S., "Biological fouling-velocity and temperature effects", The Canadian Journal of Chemical Engineering, 55, 473, Aug, 1977.

4. Melo, L.F., Pinheiro, J.D., "Particulate fouling: Controlling processes and deposit structure" in $8^{\text {th }}$ Int. Heat Transfer Conf., Paper HX-16, S. Francisco, USA, 1986.

5. Pinheiro, M.M.V.P.S., Ph. D. Thesis, Univ. Minho, Braga, Portugal, 1987.

6. Dexter, S.C. "Influence of substractum critical surface tension on bacterial adhesion - in situ studies", in Journal of Colloid and Interface Science, vol 70, no. 2, June 15, 1979,

7. Meyer, A.E., Baier, R.E., King, R.W. "Fouling of non toxic coatings in fresh, bracckish and sea water" in $36^{\text {th }}$ Canadian Chem. Eng. Conf., Sarnia, Canada, 1986.

8. Lund, D., Sandu, C., "State of art of fouling: heat transfer surfaces" in "Fundamentals and Applications of Surface Phenomena Associated with Fouling and Cleaning in Food Processing", Tylösand, Sweden, 27 Apri1 1981.

9. Duddridge, J.E., Kent, C.A., Law, J.F. "Bacterial adhesion to metallic surfaces" in Progress in the Prevention of Fouling, Nottingham University, 137, April 1981.

10. Kent, C.A. "biologial Fouling" Cont.Educ. Course, Univ. Birmingham, 23, I. Chem. Eng. March 1981.

11. Knudsen, J.G. "Fouling of Heat Transfer Surfaces" in"Workshop on Modern Developments in Marine Condensers", Monterry, California, March 1980.

12. Pinheiro, M.M.V.P.S., Melo, L.F.; Pinheiro, J.D. "Surface phenomena and hydrodynamic effects on the deposition of Pseudomonas fluorescens" in 36 th Canadian Chemical Engeneering Conf., Sarina, Canada, 1986

13. Miller, P.C., Ph.D. Thesis, Univ. Birmingham, 1982.

14. Bott, T.R., Miller, P.C., Patel, T.D., "Biofouling in an industrial cooling water system" in Process Bioch. Jan/Feb, 10, 1983.

15. Novak, L. "Control of the Rhine water fouling" in Fouling of Heat Transfer Equipment; Eds: Somerscales and Knudsen, Hemisph. Pub1. Corp., 397, 1981.

16. Hattori, R., Hattori, T., "Effect of a liquid-solid interface on the 1ife of microorganisms", in Ecological review, vol 16, no 1, 63, 1981.

17. Bott, T.R., "Biological fouling of heat transfer surfaces" in Conf. "Fouling-Art or Science?", 117, Univ. Surrey, England, 1979.

18. Hussain, C.I., M. Sc. Thesis, Univers. Birmingham, 1978.

19. Harden, V.P., Harris, J.O., "The isoelectric point of bacterial cells" in Journal Bacterio1. Vo1. 65, 198, 1953. 
20. Fletcher, M., Loeb, G.I., "Influence of substractum characteristics on the attachment of a marine Pseudomonad to solid surfaces" in Applied Environm. Microb., Vol. 37, n0 1, 67, Jan 1979.

21. Neihof, R.A., Loeb, G.I., "The surface charge of particulate matter in sea water" in Limnol. Oceanogr., vol 17, 7, 1972.

22. Mac Rae, I.C., Evans, S., "Factors influencing the adsorption of bacteria to magnetite in water and waste water" in Water Res., vol 17, no 3, $271,1983$.

23. Kornegay, B.H., Andrews, J.F.; Fina1 Report, Fed Water Pollut. Contr., 1967.

24. Schulze, K.L. Sem. Ind. Wastes, 29, 458, 1957.

25. Lowe, M.J., Duddridge, J.E., Pritchard, A.M., Bott! T.R., "Biologicalparticulate fouling interactions: effects of suspended particles on biofilm development" Symposium Series, no 86, 391, 1984.

26. Gerson, D.F., Zajic, J.E., "The biophysics of cellular adhesion" in Immobilized Microbial cells, Ed. K. Venkatsubramanian ACS Symp. Ser., 106, $29,1979$. 